\section{Funding Crisis for Australian Universities}

\section{Grant Harman}

Grant Harman is pro vice-chancellor (research) and professor of educational administration, University of New England, Armidale, New South Wales, Australia

A ustralia's 37 public universities are in shock at the prospect of drastic cuts in their funding over the next two years.

After 13 years of Labor Party rule, a conservative Liberal Party-National Party government led by John Howard took office immediately following the March 1996 federal general elections. The new government aims to reduce total government outlays by $\$ 8$ billion annually (or about 6 percent of total annual outlays) over a two-year period to address what it claims is a major deficit left by the previous Labor government.

The public universities (which constitute 37 of the 39 universities) will certainly be badly affected by these cuts, since all their regular government funding for normal operations comes from the federal government. Further, by legislation passed by the previous Labor government, universities are unable to charge tuition fees for Australian students studying for initial qualifications (generally, bachelor's degrees).

The actual size of the cuts to higher education will not be known for some months yet, since the overall government budget will not be announced until August 20, 1996. The actual allocations to each university will not be determined until close to the end of the year. But reliable leaks from the Office of the Minister for Employment, Education, Training and Youth Affairs, Senator Amanda Vanstone, predict that the cuts in operating budgets over the 1996 and 1997 calendar years combined will be between 5 percent and 12 percent.

The prospects of cuts on such a major scale have come as a real surprise to the Australian universities. No cuts of such size have been experienced by the universities since the early 1930s. Some reductions in funding were applied in the second half of the 1970s and early 1980s, and in the late 1980s during a period of rapid expansion there was some trimming of support per student unit. But substantial cuts on the scale proposed, which are not dissimilar to those experienced in the United Kingdom and elsewhere in recent years, are foreign to the current Australian university leadership. In many respects, Australian higher education experienced very favorable conditions over the past decade when total enrollments almost doubled—from about
350,000 to 630,000 students.

The cuts also came as a surprise as during the recent federal election campaign the then opposition parties, which now constitute the government, promised to maintain the existing level of funding for universities, and to increase funding for research and postgraduate scholarships. While the new government seems certain to do everything possible to honor its election promises, it argues that because of the serious financial situation it inherited it will not be able to meet all commitments in the first two years of office.

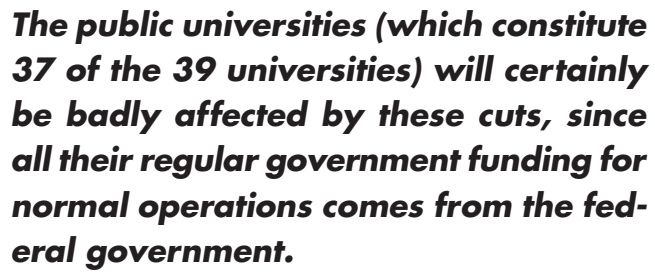

Even a uniform cut of about 6 percent across all government portfolios clearly would have a major effect on universities. But it seems likely that the cut will be in the vicinity of 10 percent to 12 percent as some areas of federal government expenditure, such defence, are unlikely to share in the cuts to any great extent, while other areas such as public debt repayments cannot be reduced. This then means that areas such as education and training, labor market programs, health, and social security will have to bear more than their share of the proposed cuts.

Universities and their related interest groups were slow to organize lobbying efforts against the proposed cuts, but in the last couple of weeks this has changed, and now an energetic campaign is under way to appeal for community support and try to change the government's plan. So far this campaign has attracted considerable media attention, and various members of the federal Parliament from both the government and opposition benches have come out in support of their local universities.

But it will be difficult to maintain this campaign for the next couple of months until the budget is finalized, and in the meantime it can be expected that groups representing health and hospital interests, aged pensioners and numerous other interests will be actively seeking community support to save their budgets.

Universities may well succeed marginally in persuading the government to lighten the burden from what has been proposed by the Department of Finance. But since the government seems strongly committed to its strategy 
of deficit reduction, substantial cuts seem inevitable.

The universities also suffer from some serious disabilities in terms of their lobbying efforts. In an egalitarian society, some of the elitist characteristics of the more traditional Australian universities mean that they often find difficulty in attracting strong public support for their causes.

Minister Vanstone has put the peak organization representing heads of universities, the Australian Vice-Chancellors' Committee (AVCC), in a difficult position in that she has twice responded to AVCC lobbying efforts by inviting the AVCC to work with her officials in advising where the cuts should be made. So far the AVCC has refused, since it has taken the public stance that there should be no cuts at all, although another reason is that representing such a diverse set of universities the AVCC would find it difficult to provide advice.

A number of individual vice-chancellors (i.e., executive heads or presidents, in American terminology), however, have not been slow to make suggestions, at least with regard to where not to make cuts and on revenue generation possibilties. Some parties representing the big eight universities, have been emphasizing the importance of maintaining funding to the strong research universities, while nonmetropolitan regional universities have been pushing for special protection. Others have effectively suggested strategies for differential treatment by advocating that the cuts should fall more heavily on the universities that have greater reserves and endowments. Others still have suggested that two or three regional universities will have to be closed.

But apart from this sectional discussion, some useful suggestions have been made. These include revenue generation suggestions as variations in the current HECS (i.e., Higher Education Contribution Scheme-effectively a graduate tax) levy and the rate of HECS liability repayment by graduates, charging of tuition fees for nonresearch higher degree enrollments, and taxation benefits for private investment in higher education. A few have also suggested an end to the embargo on the charging of tuitition fees for undergraduates.

If the cuts go ahead the end result will certainly be a trimmer and probably quite different higher education system.

\section{Democracy and Higher Education in Paraguay}

\section{Vicente Sarubbi Zaldivar}

Vicente Sarubbi is a founding member of the Advisory Council of Education Reform in Paraguay. He has taught in the Catholic University of Asuncion and has been director of a major newspaper. He is currently the director of a project to improve primary education in Paraguay and academic vice-president of the Escuela de Altos Estudios de Administración y Negocios.

ince 1989 Paraguay has been trying to establish a democracy. Extending this process will require a true educational revolution. To promote an open society, which is the foundation of democratic government, it is important to invest in basic education, science and technology in a serious and selective way. Paraguay would then be able to integrate itself with countries in the region and in the rest of the world, thus contributing to the consolidation of a nation based on law. This article highlights the most important aspects of the necessary fundamental changes within higher education in Paraguay.

It is appropriate to ponder the role of higher education at a time of crisis that calls for a deep reform of its orientation and of its institutions. This crisis is characterized by insufficient coverage, low levels of performance, insufficient and dated ideas about the functions of the university, highly bureaucratized administration, inadequate moral and intellectual development of students, lack of professional teaching standards, and irrelevance of the curriculum for the purposes of production, government, and life in general.

\section{Analysis and Prospects}

The points of analysis in this article are related, on the one hand, to the need for up-to-date scientific and technological knowledge-so essential in a modern economy-in a context of regional integration and globalization of world markets, and on the other, to the need to correct the consequences of a history of authoritarianism and corruption in the country. The professional training received is recognized as being of doubtful quality, lacking in the basic scientific knowledge and technological know-how that our times require. This means Paraguayan graduates will be at a comparative disadvantage vis à vis those of the other countries of the Southern Regional Common Market (MERCOSUR). This same deficiency in professional training limits the ability of the country-just emerging from a long period of authoritarianism and dictatorship-to produce political leaders, public and private administrators, jour- 